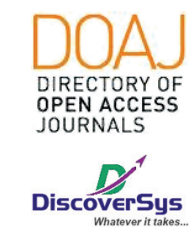

Published by DiscoverSys

\section{Prevalensi penderita skizofrenia dengan riwayat kekerasan di Rumah Sakit Jiwa Bangli Provinsi Bali}

\author{
Made Bagus Ari Pandita, ${ }^{1 *}$ Cokorda Bagus Jaya Lesmana ${ }^{2}$
}

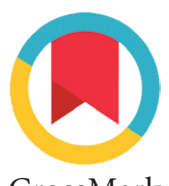

CrossMark

\title{
ABSTRACT
}

Background: Schizophrenia is a psychotic disorder that is chronic and is most often found in the community. In the community, especially Indonesia there are still many who do not understand about psychiatric disorders schizophrenia, while the incidence rate in people with schizophrenia has begun to increase. Violence in schizophrenic patients in the form of physical, psychological, sexual and economic, or threats, deprivation of freedom results in the emergence of stressors that can trigger schizophrenia with a number that continues to increase every year. Methods: This research was conducted using descriptive study design. 206 research subjects meeting the inclusion criteria were included in the study. Data that has been collected using a questionnaire will be distributed specifically based on categories and processed using SPSS 17.00 .

Results: The prevalence of Schizophrenia patients caused by violence in Bangli Mental Hospital in Bali Province is 19.9\% (41 patients) and $80.0 \%$ (165 sufferers) do not experience violence.

Conclusions: $5.8 \%$ of patients had a history of physical violence, $13.1 \%$ of patients who had a history of psychological violence, $1.0 \%$ of patients who had a history of sexual violence, and $80.1 \%$ of patients who were not found has a history of violence.

Keywords: Schizophrenia, History of Violence, prevalence

Cite This Article: Pandita, M.B.A., Lesmana, C.B.J. 2019. Prevalensi penderita skizofrenia dengan riwayat kekerasan di rumah sakit jiwa bangli provinsi bali. Intisari Sains Medis 10(3): 830-833. D0I: 10.15562/ism.v10i3.494

ABSTRAK

Latar Belakang: Skizofrenia merupakan gangguan psikotik yang bersifat kronis dan paling sering di temukan di masyarakat. Di masyarakat, kususnya indonesia masih banyak yang belum memahami tentang gangguan kejiwaan skizofrenia, sedangkan angka insiden pada penderita skizofrenia sudah mulai meningkat. Tindak kekerasan pada pasien skizofrenia berupa fisik, psikis, seksual dan ekonomi, ataupun ancaman, perampasan kebebasan mengakibatkan munculnya stressor yang bisa jadi pemicu skizofrenia dengan angka yang terus meningkat setiap tahunnya.

Metode: Penelitian ini dilakukan dengan menggunakan desain studi deskriptif. 206 subjek penelitian memenuhi kriteria insklusi diikutsertakan dalam penelitian. Data yang telah di kumpulkan menggunakan kuisioner akan didistribusi secara spesifik berdasarkan kategori dan diolah dengan menggunakan SPSS 17.00.

Hasil: Prevalensi pasien Skizofrenia yang di sebabkan oleh kekerasan di Rumah Sakit Jiwa Bangli Provinsi Bali adalah sebesar 19,9\% (41 penderita) dan yang tidak mengalami kekerasan sebanyak $80,0 \%$ (165 penderita).

Simpulan: 5,8\% penderita yang memiliki riwayat kekerasan fisik, 13,1\% penderita yang memiliki riwayat kekerasan psikis, $1,0 \%$ penderita yang memiliki riwayat kekerasan seksual, dan 80,1\% penderita yang tidak ditemukan memiliki riwayat kekerasan.
'Program Studi Pendidikan Dokter Fakultas Kedokteran Universitas Udayana

${ }^{2}$ Departemen/SMF Psikiatri RSUP Sanglah, Fakultas Kedokteran Universitas Udayana

\section{*Korespondensi:}

Made Bagus Ari Pandita, Program Studi Pendidikan Dokter Fakultas Kedokteran Universitas Udayana aripandita66@gmail.com

Diterima: 08-04-2019

Disetujui: 04-11-2019

Diterbitkan: 01-12-2019
Kata kunci: skizofrenia, riwayat kekerasan, prevalensi

Cite Pasal Ini: Pandita, M.B.A., Lesmana, C.B.J. 2019. Prevalensi penderita skizofrenia dengan riwayat kekerasan di rumah sakit jiwa bangli provinsi bali. Intisari Sains Medis 10(3): 830-833. D0l: 10.15562/ism.v10i3.494

\section{PENDAHULUAN}

Skizofrenia merupakan gangguan psikotik yang bersifat kronis dan paling sering di temukan di masyarakat, skizofrenia ditandai dengan adanya waham, pada penderita biasanya terjadi kekambuhan serta kekacauan kepribadian dan ketidakmampuan untuk berfungsi dalam kehidupan sehari - hari. Penderita skizofrenia akan kehilangan pekerjaan, teman, dan minat, karena tidak bias melakukan sesuatu, bahkan ada penderita yang hidupnya di pasung oleh keluarganya. ${ }^{1,2}$
Di masyarakat, kususnya indonesia masih banyak yang belum memahami tentang gangguan kejiwaan skizofrenia, sedangkan angka insiden pada penderita skizofrenia sudah mulai meningkat, karena penderita skizofrenia bisa dikatakan kurang mendapatkan perhatian dan penanganan secara dini dari pihak terdekat maupun tenaga medis, semakin dini penanganan penderita skizofrenia, akan semakin besar kemungkinan dan kesempatan penderita untuk dapat kembali berfungsi dengan 
lebih baik dan menjalankan kehidupan layaknya orang - orang lainnya. ${ }^{1}$

Penyakit ini menyusahkan bagi penderita maupun keluarga karena onset terjadinya kekambuhan pada dewasa di mulai umur 25 tahun. Berdasarkan jenis kelamin, pada jenis kelamin laki-laki mulai terganggu di usia 15-25 tahun, sedangkan pada jenis kelamin perempuan di usia 25-35 tahun, bias dikatakan bahwa prognosis pada jenis kelamin laki-laki lebih buruk dibandingkan dengan perempuan, dan jarang juga muncul pada anak-anak. $^{3}$

Skizofrenia dapat di pengaruhi oleh beberapa faktor yaitu: factor genetik, factor biologis, dan factor psikoanalitik. Namun factor genetik masih sangat berpengaruh dalam timbulnya gangguan kepribadian, dari hasil penelitian di Amerika Serikat mengatakan bahwa dari 15.000 pasangan kembar monozigotik, angka kesesuaian untuk gangguan kepribadian lebih tinggi dibandingkan dengan kembar dizigotik. Selain itu kondisi fisik seperti neoplasma serebral, kususnya di dairah osipitalis dan temporalis dapat menyebabkan halusinasi pada penderita gangguan akibat zat. Di dalam memeriksa penderita psikotik, kemungkinan bahwa psikosis disebabkan oleh kondisi medis umum. Pemeriksaan dengan CT-scan menunjukan adanya abnormalitas korteks cerebral, talamus, dan batang otak pada penderita skizofrenia. Selain faktor yang berkaitan dengan biologis tadi, faktor psikososial juga berperan dalam timbulnya skizofrenia. ${ }^{1,4}$

Namun sampai saat ini masih belum ada data yang relevan untuk epinemiologi skizofrenia, karena gangguan psikotik karena kondisi medis umum. Saat ini sering ditemukan penderita yang disebabkan oleh penyalahgunaan alkoholik dan zat lain atas dasar jangka panjang. Namun epidemiologi tanpa adanya kriteria diagnostik yang sepesifik, insidensi depresi pascapsikotik dari skizofrenia yang dilaporkan sangat bervariasi, mulai kurang dari $10 \%$ hingga lebih dari $70 \%$, perkiraan yang dapat di percaya dari penelitian besar adalah kira kira 25\% walaupun sampai saat ini angka insiden pasti harus menunggu hasil penelitian terkontrol yang menggunakan kriteria Diagnostic and Statistic Manual of Mental Disorder edisi ke empat (DSM-IV). ${ }^{1}$

Akan tetapi masyarakan masih memiliki pemahaman yang salah terkait dengan gangguan skizofrenia, sebagian besar orang masih banyak yang belum mendapatkan edukasi terkait dengan gangguan skizofrenia, sehingga jika salah satu dari keluarga yang mengalami gangguan psikotik tidak mendapat penanganan dengan baik dari pihak keluarga maupun petugas kesehatan. ${ }^{3}$

Sebagai Negara berkembang, kususnya di Indonesia sedang menjalani sumber daya manusia kususnya di bidang pelayanan kesehatan, akan memberikan edukai kepada masyarakat untuk meaplikasi tentang gangguan skizofrenia untuk mencegah atau mengurangi angka insiden gangguan skizofrenia yang di pengaruhi oleh kekerasan, dimana peran keluarga sangan penting untuk mengurangi angka insiden gangguan psikotik kususnya pada gangguan skizofrenia, selain itu untuk mencegah adanya kekerasan. ${ }^{4}$

Kekerasan adalah segala bentuk yang akan menyakiti secara fisik, psikis, seksual dan ekonomi, ataupun ancaman, perampasan kebebasan, sehingga para dokter dan praktisi kesehatan menyarankan agar masyarakat tadak melakukan kekerasan dalam bentuk apapun, jika mengalami suatu masalah sebaiknya di selesaikan dengan santai dan tidak menggunakan emosi untuk mengindari terjadinya kekerasan atau pertengkaran, sehingga anak - anak tidak mendapat tekanan batin dan merasa nyaman dan tenang. ${ }^{5}$

\section{METODE}

Penelitian ini merupakan penelitian deskriptif dengan desain cross-sectional untuk memperoleh gambaran umum mengenai jumlah penderita Rumah Sakit Jiwa (RSJ) Bangli Provinsi Bali yang mengalami kekerasan pada keluarga, berdasarkan pada jenis kelamin. Sampel penelitian adalah semua penderita gangguan skizofrenia yang ada di Rumah Sakit Jiwa Bangli Provinsi Bali periode 2014. 206 subjek penelitian diperoleh dengan menggunakan Teknik total sampling. Data yang digunakan adalah data sekunder melalui rekam medik pasien Rumah Sakit Jiwa Bangli selama periode 2014. Variabel yang diteliti adalah jenis kelamin, usia dan riwayat kekerasan. Data yang telah diperoleh disajikan secara deskriptif. Kemudian, dilakukan perhitungan hasil pengambilan data dalam bentuk tabel dan narasi.

\section{HASIL}

Karakteristik penderita skizofrenia pada penelitian ini usia, jenis kelamin, dan riwayat kekerasan. Karakteristik sampel dapad dilihat pada tabel 1.

Prevalensi pasien Skizofrenia yang di sebabkan oleh kekerasan di Rumah Sakit Jiwa Bangli Provinsi Bali adalah sebesar 19,9\% (41 penderita) dan yang tidak mengalami kekerasan sebanyak 80,0\% (165 penderita) (Tabel 2). 
Tabel 1 Prevalensi penderita skizofrenia di Rumah Sakit Jiwa Bangli Provinsi Bali periode 2014

\begin{tabular}{lcc}
\hline Karakteristik & Jumlah & Presentase \\
\hline Sampel Skizofrenia (N) & 206 & $100 \%$ \\
Usia & & \\
- Mean & 41,29 & \\
- Std. Deviasi & 11,821 & \\
- Minimum & 14 & \\
- Maksimum & 74 & \\
- Range & 60 & \\
Kelompok Usia & & $0,5 \%$ \\
- $\quad$ <12 Tahun & 1 & $3,4 \%$ \\
- $12-23$ Tahun & 7 & $75,7 \%$ \\
- 24-50 Tahun & 156 & 20,4 \\
- $\quad$ <0 Tahun & 42 & \\
Jenis Kelamin & & $67,5 \%$ \\
- Laki-laki & 139 & $32,5 \%$ \\
- Perempuan & 67 & $5,8 \%$ \\
Riwayat Kekerasan & 12 & $13,1 \%$ \\
- Kekerasan fisik & 27 & \\
- Kekerasan psikis & & \\
- Kekerasan seksual & & \\
- Tidak ada & & \\
\hline
\end{tabular}

Tabel 2 Prevalensi pasien Skizofrenia ya ng di sebabkan oleh kekerasan di RSJ Bangli Provinsi Bali

\begin{tabular}{lcc}
\hline Skizofrenia di RSJ Bangli Prov Bali & Frekuensi & Presentase \\
\hline Kekerasan & 41 & $20 \%$ \\
Non Kekerasan & 165 & $80,0 \%$ \\
Total & 206 & $100,0 \%$ \\
\hline
\end{tabular}

\section{DISKUSI}

Pada kelompok usia $<12$ tahun didapatkan sebanyak 1 penderita $(0,5 \%)$, pada kelompok usia 12 - 23 tahun didapatkan sebanyak 7 penderita $(3,4 \%)$, pada kelompok usia 24 - 50 tahun didapatkan sebanyak 156 penderita $(75,7 \%$, dan pada kelompok usia $>50$ tahun didapatkan sebanyak 42 penderit $(20,4 \%)$ a. Pada penelitian yang dilakukan oleh Yulia (2013), menyebutkan bahwa penderita skizofrenia berdasarkan kelompok usia didapatkan pada kelompok uasia 19 - 25 tahun sejumlah 17 penderita (12\%), pada kelompok usia 26 - 35 tahun sejumlah 33 penderita ( $23,2 \%$ ), pada kelompok usia 36 - 46 tahun sejumlah 49 penderita $(34,5 \%)$, pada kelompok usia 46 - 55 tahun sejumlah 34 penderita (23,9\%), dan pada kelompok usia 56 - 65 tahun sejumlah 9 penderita $(6,3 \%)$. Yang terbanyak didapat pada penelitian ini didapat pada kelompok usia 36 - 45 tahun sebanyak 34,5\% hal ini sesuai dengan hasil penelitian yang dilakukan di Rumah Sakit Jiwa Bangli Provinsi Bali sebanyak $75,7 \%$ ditemukan pada kelompok umur $24-50$ tahun. ${ }^{6}$

Berdasarkan jenis kelamin, penderita skizofrenia yang di pengaruhi oleh kekerasan pada laki - laki didapatkan 139 penderita (67,5\%) sedangkan pada jenis kelamin perempuan didapatkan 67 penderita (32,5\%). Dari hasil penelitian ini didapatkan bahwa sebagian besar penderita skizofrenia yang di pengaruhi oleh kekerasan, terdapat pada jenis kelamin laki - laki dibandingkan dengan perempuan. Pada penelitian Erlina, dkk tahun 2010 menyebutkan pada kelompok jenis kelamin laki - laki penderita skizofrenia berjumlah 54 (72\%), dan kelompok jenis kelamin perempuan penderita skizofrenia berjumlah $21(28 \%) .^{7}$ Hal ini sesuai dengan penelitian yang telah dilakukan di Rumah Sakit Jiwa Bangli Provinsi Bali yang menemukan pada kelompok jenis kelamin laki - laki sebanyak 139 (67,5\%) penderita.

Berdasarkan riwayat kekerasan, penderita skizofrenia yang di pengaruhi oleh kekerasan pada kekerasan fisik didapatkan 12 penderita $(5,8 \%)$ pada kekerasan psikis didapatkan 27 penderita $(13,1 \%)$ pada kekerasan seksual didapatkan 2 penderita $(1,0 \%)$ dan pada penderita yang tidak ditemukannya riwayat kekerasan didapatkan 165 penderita (80,1\%). Pada penelitian yang di lakukan oleh kazadi tahun 2008 mengatakan bahwa pada penderita skizofrenia kejadian yang menyebabkan stress tidak berhubungan dengan kambuhnya pasien namun pada pasien dengan kekambuhan tingkat kejadian yang menyebabkan stress lebi banyak frekuensinya dengan pasien yang tidak kambuh. Kemudian data juga menunjukkan bahwa penyebab tersering terjadinya stress pada penelitian ini adalah hubungn relationship $(33,8 \%)$, death $(23,9 \%)$, financial $(16,2 \%)$, other $(18,9 \%)$, personal injury $(11,1 \%) .{ }^{8}$ Terdapat kesamaan antara penelitian ini dengan penelitian yang dilakukan di Rumah Sakut Jiwa Bangli Provinsi Bali berupa aspek psikososial masih lebih besar frekuensinya dibanding aspek - aspek yang lain dalam menyebabkan stress pada penderita skizofrenia.

Pada penelitian Kazadi tahun 2009 menemukan bahwa pada penderita skizoprenia frekuensi kekerasan "Life Stressor" berjumlah 90 (41\%) pada 217 sampel, kemudian pada kategori non kekerasan berturut-turut "Co-morbid psychiatric disorder" berjumlah 70 (32,2\%), Depressed Mood berjumlah 59 (27,1\%), Co-morbid Medical Disorder berjumlah 64 (29.4\%), dan Substance Abuse berjumlah 88 (40,5\%). Penelitian ini menunjukan bahwa penderita skizofrenia dengan riwayat kekerasan lebih tinggi frekuensinya $(\mathrm{n}=90,41 \%)$ dibanding dengan non kekerasan. Hal ini sedikit berbeda 
dengan penelitian yang dilakukan di Rumah Sakit Jiwa Bangli yang menunjukan bahwa penderita skizoprenia dengan riwayat kekerasan $(n=165$, $80 \%$ ) frekuensinya lebih rendah disbanding riwayat non kekerasan. ${ }^{8}$ Perbedaan hasil penelitian ini dikarenakan akibat berbedanya demografis studi antara kedua penelitian ini. Selain itu, perbedaan juga disebabkan belum terkategorikannya kelompok non-kekerasan pada penelitian ini sehingga menyebabkan perbedaan.

\section{SIMPULAN}

Berdasarkan penelitian dari 206 penderita, didapatkan prevalensi pasien Skizofrenia yang di sebabkan oleh kekerasan di Rumah Sakit Jiwa Bangli Provinsi Bali adalah sebesar 20\% (41 penderita) dan yang tidak mengalami kekerasan sebanyak 80,0\% (165 penderita).Berdasarkan riwayat kekerasan ditemukan, 5,8\% penderita yang memiliki riwayat kekerasan fisik, $13,1 \%$ penderita yang memiliki riwayat kekerasan psikis, $1,0 \%$ penderita yang memiliki riwayat kekerasan seksual, dan $80,1 \%$ penderita yang tidak ditemukan memiliki riwayat kekerasan.

\section{KONFLIK KEPENTINGAN}

Penulis menyatakan tidak terdapat suatu konflik kepentingan terhadap publikasi dari artikel ini

\section{PENDANAAN}

Penelitian ini tidak mendapatkan suatu pendanaan yang diberikan oleh pemerintah ataupun lembaga swasta lainnya.

\section{KONTRIBUSI PENULIS}

Konsep penelitian: Made Bagus Ari Pandita ${ }^{1}$, Cokorda Bagus Jaya Lesmana ${ }^{2}$. Pengumpulan data, input data dan pengolahan data: Made Bagus Ari Pandita. Penyusunan naskah Penelitian: Made Bagus Ari Pandita.

\section{ETIKA DALAM PENELITIAN}

Penelitian ini telah disetujui oleh Komite Etik Fakultas Kedokteran Universitas Udayana.

\section{DAFTAR PUSTAKA}

1. Saddock BJ dan Sadock VA. Schizophrenia. In: Kaplan\&sadock's synopsis of psychiatry: behavioral sciences/clinical psychiatry. Philadelphia: Lippincott Williams \& wilkins; 2007. pp 467-497.

2. PPDGJ III: Pedoman penggolongan dan diagnostik gangguan jiwa di Indonesia III: Skizofrenia, gangguan skizotipat dan gangguan waham. Jakarta: Departemen Kesehatan; 1993.p. 103-135.

3. Heinz, Hafner dan Wolfram an der Heiden. Epidemiology of Schizophrenia. Can J Psychiatry, Vol 42, March 1997: 139-151.

4. Nurmiati, Amir. Majalah jiwa psikiatri: Perempuan dengan skizofrenia. Yayasan kesehatan jiwa Dharmawangsa, Jakarta; 2009.p. 19-35.

5. Rochmat, Wahab. Kekerasan Dalam Rumah Tangga. Perspektif Psikologis dan Edukatif. January 2003. 1-15.

6. Yulia, Jarut, Fatimawali dan Weny I. Wiryono. Tinjauan Penggunaan Antipsikotik Pada Pengobatan Skizofrenia di Rumah Sakit PROF. DR. V. L. Ratumbuysang Manado Periode Januari 2013-Maret 2013. Jurnal Ilmiah FarmasiUnsrat Vol 2 no 3.

7. Erlina, dkk. Determinan Terhadap Timbulnya Skizofrenia Pada Pasien Rawat Jalan di Rumah Sakit Jiwa Prof. HB Saanin Padang Sumatera Barat. Berita Kedokteran Masyarakat. Juni 2010. Vol 26, No 2,

8. Kazadi, N J B Et al. Factor Associated with Relapse in Schizophrenia. Volume 14 No. 2 Juni 2008: SAJP.

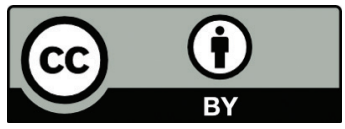

This work is licensed under a Creative Commons Attribution 